\section{WITHOUT PREJUDICE}

What a tragedy it is that Sigerist did not live to complete his ambitiously conceived $A$ History of Medicine: only two volumes of the projected eight were published, the first in 1951 and the second, posthumously, in 1961. In the first he made good the neglect of Egyptian medicine in some medical histories, though it should be recorded that in the 1929 edition of Garrison the ground was covered in some detail in a smallscale but precisely drawn map.

Sigerist is in no doubt-any more than Herodotus wasabout the debt the Greeks owed to the Egyptians. The ancient Egyptian doctor examined his patient by inspection, palpation, and smell. And he asked his patients the right questions. To someone with an injured spinal column he said, "Extend now thy two legs and contract them both again." The Egyptian dentist was far enough advanced in the IVth Dynasty to drill holes to drain a dental abscess. In the same tomb which revealed this fact " $H$. Junker found two teeth, a second and third left lower molar, linked together by gold wire. . . ."

"There can be no doubt whatsoever," writes Sigerist, " that the Greeks learned a great deal from Egypt." In the beautifully illustrated history edited by Laignel-Lavastine Dr. FournierBégniez says that Hippocrates, Pliny, Dioscorides, and Galen all borrowed much from the most ancient of civilizations. Which is after all what one would expect if the civilization was as high as it was old. Fournier-Bégniez endorses Breasted's verdict that the Edwin Smith papyrus was a scientific treatise. "These discussions demonstrate," Breasted wrote, "the surgeon's scientific interest in the human body as a field of observation, and disclose him to us as the earliest scientific mind which we can discern in the surviving records of the past." Sigerist does not go all the way with this conclusion. But Fournier-Bégniez gives this opinion on the Edwin Smith papyrus: "La méthode d'exposition, les procédés d'exploration, le verdict constant, l'élimination de la magie, la valeur anatomique, clinique et thérapeutique, démontrent un niveau déjà élevé de l'art médical. Bien plus, ce manuscrit mutilé est aussi l'acte de naissance de l'esprit scientifique proprement dit. . . ."

Both the Ebers papyrus and the Edwin Smith were written about the same time-round 1600 B.c. But they are copies of much earlier texts, it appears, texts that may go back to the Pyramid Age, getting close in fact to the first historic physician of all time, Imhotep.

To me the time-span of events is of special interest. Three thousand years between the writing of the Edwin Smith and Ebers papyri and the publication of the London pharmacopoeia. Four thousand years and more between State medicine in Ancient Egypt and what Great Britain today likes to think is a revolution in the provision of medical services. (With some forcible self-restraint I avoided putting an exclamation mark at the end of the last sentence, having been taught that the only proper place for it is after an exclamation.)

But the fact that Ancient Egypt and Greece had a State Medical Service does put me against it. We may even be right in copying them, as we have done in so much else, though I doubt it. But the extreme antiquity of these ideas and practices does at least, I hope, put them into perspective. There is no new thing under the sun!

As far back as 2500 B.c. there was a Superintendent of Court Physicians, and the Court, as Sigerist puts it, was served by a whole collegium of doctors. One description of office is found unchanged in inscriptions on various monuments from the Pyramid Age to the XXXth Dynasty-that is, approximately from 2500 B.C. to 400 B.c.: the time-span between Imhotep and Hippocrates. "Greatest Physician of Lower and Upper
Egypt" was a title that held its own sway for over 2,000 years. The Ancient Egyptians had a passion for rank and order of precedence, at least in respect of their physicians.

At the bottom of the medical pyramid was the ordinary doctor, and then in ascending steps of prestige and priority came the Chief of Physicians, the Inspector of Physicians, and the Superintendent. As to the supreme title mentioned earlier, it is thought that this was the title of the chief medical officer of the country, "who supervised the activities of the profession and might also have served as intermediary between the practitioners and ... a kind of Ministry of Health." The head of this was known as the "Administrator of the House of Health and Chief of the Secret of Health in the House of Thoth"-the direct ancestor, so to say, of Mr. Kenneth Robinson.

This extreme "hierarchization," Sigerist says, may seem strange to us ; "but," he adds, "we should not forget that we have it also. ..."

The written text-the case of writings-was a great power in the land. According to Diodorus " the physicians draw their support from the public funds, and administer their treatments in accordance with the written law, which was composed in ancient times by many famous physicians. If they follow the rules of this law as they read them in the sacred book, and yet are unable to save their patient, they are absolved from any charges and go unpunished. But if they go contrary to the law's direction in any respect, they must submit to trial, with death as the penalty: the lawgiver holding that but few physicians would ever show themselves wiser than to adopt the mode of treatment which had been originally described by the ablest physicians."

An English historian has described this complicated rule of administrative law as the most complete and all-pervading bureaucratic organization before modern times.

The public doctors of Ancient Egypt, the panel doctors of the time, were all under the ultimate control of a State official and were as a rule paid a salary by the State. To meet the cost of the health service the citizen paid a yearly tax in wheat. In exceptional circumstances this could be given direct to the doctor.

Public doctors were allowed to accept presents trom wealthy patients, according to the German historian Sudhoff, who notes that the public doctors were considered to be more efficient than private practitioners. This too was the view in Greece. "What an absurdity," says Socrates, "to think that we or any human being should be so silly as to set up as a State physician, and advise others like ourselves to do the same, without having first practised as private doctor. . .." The State doctors in Greece had a high reputation and were paid well-so well that one of them when his city was in financial straits gave up a month's salary for the common good.

Inscriptions on monuments in Greece show that this sort of activity was by no means uncommon. In return the Greek physician was honoured and rewarded. One doctor was freed from his obligation to pay taxes. Many city-states gave their doctors golden crowns. But how long this golden age lasted I don't know. When Athens was beginning to recover from the terrible Peloponnesian war there was, according to Aristophanes in his play Plutus, a shortage of physicians in the city. The god of wealth is blind. "Had we not better," says one citizen to another, "call a doctor ?" And there comes the reply: "Is there a doctor now anywhere in town? There are no fees, and therefore there's no skill."

And so it goes on ding dong bell throughout the centuries, the tale of public versus private enterprise.

\section{PERTINAX}

